\title{
Aflatoxin $B_{1}$ albumin adducts in plasma and aflatoxin $M_{1}$ in urine are associated with plasma concentrations of vitamins $A$ and $E$
}

\author{
Francis A. Obuseh ${ }^{1}$, Pauline E. Jolly², Yi Jiang ${ }^{2}$, Faisal M. B. Shuaib², John Waterbor ${ }^{2}$, \\ William O. Ellis ${ }^{3}$, Chandrika J. Piyathilake ${ }^{4}$, Renee A. Desmond ${ }^{5}$, Evans Afriyie-Gyawu ${ }^{6}$, \\ and Timothy D. Phillips ${ }^{6}$ \\ ${ }^{1}$ Department of Maternal and Child Health, University of Alabama at Birmingham, Birmingham, \\ USA \\ ${ }^{2}$ Department of Epidemiology, University of Alabama at Birmingham, Birmingham, USA \\ ${ }^{3}$ Department of Biochemistry, Kwame Nkrumah University of Science and Technology, Kumasi, \\ Ghana \\ ${ }^{4}$ Nutritional Biochemistry and Genomics, University of Alabama at Birmingham, School of Health \\ Professions, Birmingham, USA \\ ${ }^{5}$ Division of Preventive Medicine, School of Medicine, University of Alabama at Birmingham, \\ Birmingham, USA \\ ${ }^{6}$ College of Veterinary Medicine, Texas A \& M, Texas, USA
}

\section{Abstract}

\begin{abstract}
Background-Although aflatoxin exposure has been shown to be associated with micronutrient deficiency in animals, there are few investigations on the effects of aflatoxin exposure on micronutrient metabolism in humans.
\end{abstract}

\begin{abstract}
Objective-To examine the relationship between aflatoxin $\mathrm{B}_{1}\left(\mathrm{AFB}_{1}\right)$ albumin adducts $(\mathrm{AF}-$ ALB) in plasma and the aflatoxin $\mathrm{M}_{1}\left(\mathrm{AFM}_{1}\right)$ metabolite in urine and plasma concentrations of retinol (vitamin A) and $\alpha$-tocopherol (vitamin E) in Ghanaians.
\end{abstract}

Methods-A cross-sectional study of 147 adult participants was conducted. Blood and urine samples were tested for aflatoxin and vitamins A and E levels.

Results-Multivariable analysis showed that participants with high AF-ALB $(\geq 0.80 \mathrm{pmol} / \mathrm{mg}$ albumin) had increased odds of having vitamin A deficiency compared to those with lower AFALB [Odds Ratio $(\mathrm{OR})=2.61 ; \mathrm{CI}=1.03-6.58 ; \mathrm{p}=0.04$ ]. Participants with high AF-ALB also showed increased odds of having vitamin $\mathrm{E}$ deficiency but this was not statistically significant $(\mathrm{OR}=2.4 ; \mathrm{CI}=0.96-6.05 ; \mathrm{p}=0.06)$. Conversely, those with higher $\mathrm{AFM}_{1}$ values had a statistically nonsignificant reduced odds of having vitamin A deficiency $(\mathrm{OR}=0.31 ; \mathrm{CI}=1.15$ $0.09 ; \mathrm{p}=0.05)$ and statistically significant reduced odds of having vitamin $\mathrm{E}$ deficiency $(\mathrm{OR}=$ $0.31 ; \mathrm{CI}=0.10-0.97 ; \mathrm{p}=0.04)$. Participants with high AF-ALB or high $\mathrm{AFM}_{1}(\geq 437.95 \mathrm{pg} / \mathrm{dL}$ creatinine) were almost 6 times more likely to be hepatitis B virus surface antigen (HBsAg)positive $(\mathrm{OR}=5.88 ; \mathrm{CI}=1.71-20.14 ; \mathrm{p}=0.005)$ and $(\mathrm{OR}=5.84 ; \mathrm{CI}=1.15-29.54 ; \mathrm{p}=0.03)$ respectively.

Conclusions-These data indicate that aflatoxin may modify plasma micronutrient status. Thus, preventing aflatoxin exposure may greatly reduce vitamins $\mathrm{A}$ and $\mathrm{E}$ deficiencies.

Corresponding Author: Pauline E. Jolly, PhD, MPH, Department of Epidemiology, Rm. 217, Ryals School of Public Health, University of Alabama at Birmingham, 1665 University Blvd, Birmingham, Alabama 35294-0022. 


\section{Keywords}

Aflatoxin; Vitamin A; Vitamin E; Hepatitis B Virus; Ghana

\section{Introduction}

Micronutrients play a critical role in maintaining proper functioning of the immune system and so are important in reducing morbidity and mortality from infectious diseases. Deficiencies in micronutrients are prevalent among people worldwide and, although debilitating for all age groups, have the greatest impact on pre-school children and pregnant women. Epidemiological data has shown that 140-250 million children worldwide are at risk for vitamin A deficiency-related disorders annually despite global initiatives to eliminate micronutrient deficiencies [1]. Over 7 million pregnant women in developing countries suffer from vitamin A deficiency every year [2]. This increases morbidity and mortality during pregnancy and the early postpartum period [3, 4].

Vitamin A is a fat-soluble micronutrient that is essential for immunity, cellular differentiation, maintaining epithelial surfaces, growth, reproduction and vision [5]. Vitamin A deficiency has been associated with severe cases of measles, pneumonia and diarrhea in children [6-8]. Jiang et al. [9] recently showed that vitamin A was prevalent in the Ghanaian population and associated with the impairment of innate and cytotoxic immune function. Vitamin A deficiency has also been shown to be associated with the development of hepatocellular carcinoma (HCC) [10]. Huang et al. [11] showed that vitamin A has a protective effect on cancer by not only inhibiting the metabolic activation of carcinogens but also by preventing the initial steps in carcinogenesis.

Vitamin $\mathrm{E}$ is a lipid soluble antioxidant that decreases free radical-induced damage to cellular membranes. Results from human and animal studies indicate that vitamin E plays an important role in maintenance of the immune system [12]. A study in healthy humans showed that vitamin E supplementation increased $\mathrm{CD} 4 / \mathrm{CD} 8 \mathrm{~T}$ cell ratio, enhanced T-cell proliferation and lowered measures of oxidative stress $\left(\mathrm{H}_{2} \mathrm{O}_{2}\right.$ production) [13].

Epidemiological and experimental studies suggest that dietary antioxidants such as vitamin E may suppress chemically induced carcinogenesis through a variety of mechanisms [14]. Deficiencies of vitamins A and E are associated with HIV disease progression and mortality [15].

Aflatoxins are metabolites of some Aspergillus species of fungi and are the most potent hepatotoxic and hepatocarcinogenic mycotoxins known [16]. Acute aflatoxicosis results in illness and death in humans [17, 18]. In studies conducted in Africa, exposure to food-borne aflatoxins is common [19-21]. Maize and groundnuts are excellent substrates for production of aflatoxins [17, 18]. Kpodo et al. [21] and Awuah and Kpodo [22] reported high levels of aflatoxin in maize and groundnut samples in Ghana. Aflatoxin intake is associated with an increased risk of hepatocellular carcinoma (HCC) especially in people with hepatitis B virus (HBV) infection [23]. Serum aflatoxin is also a risk factor for neonatal jaundice and morbidity in infants [24-26], infertility [27], and malnutrition and lack of disease resistance in livestock and laboratory animals [28].

Animal studies indicate that exposure to aflatoxin may reduce plasma and tissue vitamin A [29-32] and vitamin E concentrations [33]. In some cases, supplementation of vitamins A and $\mathrm{E}$ ameliorated aflatoxin-induced changes and inhibited aflatoxin-induced carcinogenesis through anti-mutagenic effect [34-36]. Nyandieka et al. [37] investigated the influence of nutritional factors on aflatoxin-induced liver tumors in rats and found that the development 
of tumors as a result of aflatoxin exposure was totally inhibited by the ingestion of vitamin A. They also observed that vitamin E inhibited the development of aflatoxin-induced liver cancer.

Micronutrient deficiencies commonly occur in large proportions of the populations of many developing countries and exposure to dietary aflatoxin further aggravates the deficiencies. Thus, reduction in exposure to aflatoxin could be considered a significant public health intervention. The finding of an association between aflatoxin and micronutrient deficiencies from numerous animal studies suggests that there may be a relationship between aflatoxin biomarkers [aflatoxin $\mathrm{B}_{1}$ albumin adduct (AF-ALB) in plasma and aflatoxin $\mathrm{M}_{1}\left(\mathrm{AFM}_{1}\right)$ in urine] and vitamins $\mathrm{A}$ and $\mathrm{E}$ concentrations in humans. Based on this hypothesis, we predicted that we would see correlations between aflatoxin biomarkers with vitamin $\mathrm{A}$ and $\mathrm{E}$ concentrations.

\section{Materials and Methods}

\section{Participants and study area}

The study population consisted of adults ( $\geq 19$ years) from the Ejura Sekyedumase district in the Ashanti Region of Ghana. This is a major groundnut- and maize-producing and consuming region in southern Ghana. A cross-sectional study was conducted to determine the relationship between aflatoxin and plasma concentrations of vitamins $\mathrm{A}$ and $\mathrm{E}$ in our study participants. Our targeted sample size was 150 participants. This was based on the 25 $\mu \mathrm{g} / \mathrm{dL}$ difference in expected effect size that we predicted we would see among those with high and low concentrations of vitamin A using the t-test with a power of $80 \%(\beta=0.20)$ and $\alpha=0.05$. The sample consisted of volunteers within four communities in the district. Pregnant women and those with acute infections were excluded since pregnancy and acute infections could affect micronutrient status. We enrolled 147 eligible participants who gave signed, informed consent. Approval for the study was obtained from the Institutional Review Board at the University of Alabama at Birmingham (UAB) and from the Ethics Committee, School of Medical Sciences, Kwame Nkrumah University of Science and Technology (KNUST), Kumasi, Ghana.

\section{Sample collection, preparation and analysis}

Each participant completed a survey that consisted of questions on sociodemographic, health, food, and food consumption characteristics. Twenty milliliters of venous blood was drawn from each subject using sterile needles and vacutainer tubes. The tubes were wrapped in foil to reduce the effect of oxidation and light on retinol. Blood was transported to the laboratories of the Kumasi Center for Collaborative Research (KCCR) in Tropical Medicine at KNUST within 6 hours of collection. Plasma was collected and aliquoted into vials for analysis of retinol, tocopherol, liver function, anti-hepatitis B surface antigen (HBsAg), antihepatitis $\mathrm{C}$ virus antibody (HCV Ab), and AF-ALB levels. The vials containing plasma for retinol and tocopherol analysis were wrapped in aluminum foil and kept in thick black polythene bags at $-80^{\circ} \mathrm{C}$. Urine samples (first urine the morning after recruitment) were obtained from 82 of the 147 participants and stored at $-80^{\circ} \mathrm{C}$. All samples were subsequently air-transported frozen to $\mathrm{UAB}$ and kept at $-80^{\circ} \mathrm{C}$ until analyzed.

\section{Simultaneous determination of vitamin A (retinol) and vitamin $E$ ( $\alpha$-tocopherol) in plasma}

Serum retinol is a useful indicator of vitamin A status since serum retinol concentration is normally maintained within a narrow range in individuals with adequate vitamin A stores. Alpha-tocopherol is the most active component of the vitamin E complex. A modified version of the high-performance liquid chromatography (HPLC) procedure developed by 
Stacewicz-Sapuntzakis et al. [38] was used to measure both vitamins A and E in plasma. Details of the method have been published previously [9].

\section{Determination of AF-ALB levels in plasma by radioimmunoassay (RIA)}

AF-ALB levels in plasma from study participants were determined by radioimmunoassay (RIA) [39]. The assay measures aflatoxin that is covalently bound in peripheral blood albumin and reflects aflatoxin exposure in the previous 2-3 months. Plasma samples were concentrated by high-speed centrifugal filtration, and the concentrated protein was resuspended in phosphate-buffered saline (PBS). Plasma albumin was determined by using a bromocresol purple dye binding method (Sigma, St. Louis, MO), and the amount of total protein was determined by using the Bradford procedure (San Rafael, CA). Total protein per sample was then digested with Pronase (Calbiochem, La Jolla, CA), and bound aflatoxin was extracted with acetone. The RIA procedure [39] was used to quantify AF-ALB in duplicate plasma protein digests that each contained $2 \mathrm{mg}$ of protein. Nonspecific inhibition in the assay was determined by processing pooled, normal human plasma standards (Sigma, St. Louis, MO). The standard curve for the RIA was determined by using a nonlinear regression method [40]. The concentrations of albumin, total protein, and AF-ALB in individual plasma samples were calculated and the values were expressed as the amount of AF-ALB per milligram of albumin [39]. The detection limit of the assay was $0.01 \mathrm{pmol} / \mathrm{mg}$ albumin.

\section{Determination of the $\mathrm{AFM}_{\mathbf{1}}$ metabolite in urine}

Metabolic levels of $\mathrm{AFM}_{1}$ in urine were quantitated by HPLC after immunoaffinity cleanup of samples. $\mathrm{AFM}_{1}$ metabolite was used as a valid indicator of short-term exposure to aflatoxins because of its prevalence in the urine and because of its dose-dependent relationship with $\mathrm{AFB}_{1}$ intake in the diet [41]. Affinity chromatography cleanup procedures and HPLC analysis were based on methodologies described by Groopman et al. [42], along with the modifications of Sarr et al. [43] and Wang et al. [44]. Each of the urine samples $(5.0 \mathrm{~mL})$ was adjusted to an acidic $\mathrm{pH}$ with $0.5 \mathrm{~mL}$ of $1.0 \mathrm{M}$ ammonium formate $(\mathrm{pH} 4.5)$, and the volume was increased to $10 \mathrm{ml}$ with water and, and then vortexed. The sample was then applied to a 1-mL preparative Aflatest $\mathrm{P}$ monoclonal antibody column (VicamLP, Watertown, MA), and aflatoxin was eluted at a flow rate of approximately $0.3 \mathrm{ml} / \mathrm{min}$ as described previously [44]. For HPLC analysis, a Waters HPLC system (Waters Corporation, Milford, MA) with fluorescence detection capabilities was used. A $250 \mathrm{~mm} \times 4.6 \mathrm{~mm}$ LiCrospher RP-18 end-capped column with pore size $100 \mathrm{~A}$ and particle size $5 \mu \mathrm{m}$ (Alltech Associates, Deerfield, IL) was used to resolve aflatoxin metabolites. The mobile phase consisted of $22 \%$ ethanol in water that was buffered with $20 \mathrm{mM}$ ammonium formate $(\mathrm{pH}$ 3.0). Chromatographic separation of aflatoxin was achieved by isocratic elution of the mobile phase for 20 minutes. Samples were injected $(100 \mu \mathrm{L})$ on the column and the elution rate was $1.0 \mathrm{~mL} /$ minute. $\mathrm{AFM}_{1}$ peaks were detected at a retention time of approximately 15.4 minutes. The limit of detection for this method was $10 \mathrm{pg} / \mathrm{mL}$ of urine for $\mathrm{AFM}_{1}$. The identity of $\mathrm{AFM}_{1}$ was confirmed by gas chromatography/mass spectrometry (GC/MS) by comparing standards (Sigma, Milford, MO) [45]. Urinary concentrations of $\mathrm{AFM}_{1}$ metabolite were expressed as $\mathrm{pg} / \mathrm{mg}$ of creatinine to correct for variations in urine dilution among individual samples.

\section{Test for antibodies to HBV surface antigen}

HBsAG in plasma samples was determined using the Bio-Rad Enzyme Immunoassay according to the manufacturer's directions (Bio-Rad, Redmont, WA, USA). A sample was considered initially reactive for anti-HBsAg if the absorbance value was greater than or equal to the mean absorbance value of the negative controls plus 0.07 according to the 
manufacturer's instructions. Positive samples were determined by repeated reactivity in duplicate tests.

\section{Test for HCV antibody in plasma}

Qualitative detection of antibody to HCV in plasma was conducted using the Abbott HCV Enzyme Immunoassy according to the manufacturer's directions (Abbott Laboratories, Abbott Park, IL, USA). Test samples with an optical density (OD) greater or equal to the mean absorbance of the three negative controls, plus 0.25 times the mean absorbance of the 3 positive controls, were considered initially reactive by the criteria of Abbott HCV EIA 2.0. Positive samples were determined by repeated reactivity in duplicate tests.

\section{Analysis of serum markers for liver function (transaminases, bilirubin, total blood protein and plasma albumin)}

A complete hepatic function profile was conducted on plasma from the study participants. This included tests of the liver enzyme aspartate transaminase (AST) and alanine transaminase (ALT), liver transport (total bilirubin), and liver synthesis (serum albumin and total blood protein). The tests were performed at the UAB Hospital Laboratory.

\section{Statistical analysis}

Descriptive statistics are presented as means $( \pm \mathrm{SD})$ or medians and interquartile ranges. The relationships between demographics, behavioral, and clinical variables were examined by using the chi-square test. For comparison across groups, the median was used to categorize aflatoxin values into high and low categories.

We used the World Health Organization's (WHO) generally accepted cutoff value for micronutrient deficiencies for retinol and tocopherol $(<0.698 \mu \mathrm{mol} / \mathrm{L}$ and $<11.6 \mu \mathrm{mol} / \mathrm{L}$ respectively) [46] to group participants into micronutrient-sufficient (normal) and -deficient groups. Cutoff points were based by WHO on tissue concentrations low enough to cause adverse health outcomes. We then examined the frequency distribution of the micronutrient variables and the demographics of the study population. Because these variables were categorical, a series of chi-square tests were performed to determine the relationships between them. Univariate associations between continuous variables were performed using the Spearman correlation coefficient. Differences in aflatoxin concentrations by retinol, tocopherol, and liver function parameters were evaluated by using the Kruskal-Wallis test due to non-normality of the data.

We constructed regression models using theoretical concepts and the independent variables that were associated with the exposure variables in the chi-square analysis at the 0.10 level or less. Unconditional logistic regression models were run separately for predicting deficiencies in retinol and tocopherol levels by aflatoxin. We controlled for other known risk factors and confounders such as ethnicity, anti-HBsAg positive test results, total plasma protein, albumin bilirubin, and AST levels. All tests of hypotheses were two-tailed, with a type I error rate fixed at 5\%. All statistical analyses were conducted using the statistical software package SAS Version 9.1 (SAS Institute, Cary, NC).

\section{Results}

\section{Concentrations of AF-ALB, AFM 1 , vitamin $A$ and vitamin $E$ in study population}

Plasma samples from 145 participants were tested for AF-ALB and vitamins A and E concentrations. $\mathrm{AFM}_{1}$ levels were determined in 82 urine samples. The median concentration of AF-ALB was $0.80(\mathrm{SD} \pm 0.46) \mathrm{pmol} / \mathrm{mg}$ albumin $($ mean $=0.899$; range $=$ 0.120-2.994 $\mathrm{pmol} / \mathrm{mg}$ albumin). The median $\mathrm{AFM}_{1}$ concentration was 437.95 (SD \pm 2451$)$ 
$\mathrm{pg} / \mathrm{dL}$ of urine creatinine, $($ mean $=1646.12 ;$ range $=0-11,562.36 \mathrm{pg} / \mathrm{dL}$ of urine creatinine $)$. All participants were positive for AF-ALB and $91.2 \%$ were positive for $\mathrm{AFM}_{1}$. The mean vitamin A concentration was 1.13 ( $\mathrm{SD} \pm 0.72) \mu \mathrm{mol} / \mathrm{L}$ with an interquartile range (IQR) of $0.65-1.54 \mu \mathrm{mol} / \mathrm{L}$; the mean plasma vitamin E concentration was $9.52(\mathrm{SD} \pm 6.73) \mu \mathrm{mol} / \mathrm{L}$ (IQR of $5.57-12.54 \mu \mathrm{mol} / \mathrm{L}$ ).

\section{Sociodemographic and biological characteristics of the study population by sex}

Table I presents the descriptive sociodemographic and biological characteristics of the study population by sex. The mean age for the study group was $39.0(\mathrm{SD} \pm 16.2)$ years. A majority of the study participants were Akans (37.8\%), and $48 \%$ had formal education; $60 \%$ were involved in farming. Significantly more males than females had formal education $(p=0.0004)$ and were farmers $(p<0.0001)$. The prevalence of vitamins $A$ and $E$ deficiencies (plasma vitamin $\mathrm{A}=<0.698 \mu \mathrm{mol} / \mathrm{L}$ and plasma vitamin $\mathrm{E}<11.6 \mu \mathrm{mol} / \mathrm{L}$ ) was $31.7 \%$ and $73.1 \%$, respectively. There were no statistically significant sex differences in vitamins A and E concentrations and the biological markers for aflatoxin. Women reported slightly lower levels of alcohol use and smoked less than men $(\mathrm{p}<0.05)$. With regard to hepatitis infection, approximately $16 \%$ of the participants were positive for $\mathrm{HBsAg}$ and $15 \%$ were positive for $\mathrm{HCV} \mathrm{Ab}$.

\section{Sociodemographic characteristics of the study population by vitamin A status}

Table II shows the descriptive statistics of the study population by vitamin A status. There were significant differences between vitamin A concentrations and variables such as ethnicity, having a positive anti-HBsAg test result, vitamin E, AF-ALB, and $\mathrm{AFM}_{1}$. Participants with low vitamin A concentrations had significantly increased levels of AFALB $(\mathrm{p}=0.005)$, and positive anti-HBsAg test results $(\mathrm{p}=0.002)$. There was no significant association between age and vitamin A concentrations. Those with low vitamin $\mathrm{A}$ concentrations had significantly lower levels of $\mathrm{AFM}_{1}(\mathrm{p}=0.02)$. Analysis of vitamin $\mathrm{E}$ and aflatoxin levels demonstrated that there was a trend towards lower vitamin $\mathrm{E}$ concentrations in participants with high AF-ALB levels ( $\mathrm{p}=0.07)$, and towards lower vitamin $\mathrm{E}$ concentrations in individuals with low $\mathrm{AFM}_{1}(\mathrm{p}=0.08)$. Individuals with low vitamin $\mathrm{E}$ levels had high AF-ALB and low $\mathrm{AFM}_{1}$ concentrations (data not shown).

\section{Correlation between variables}

The relationship between vitamin A, vitamin E, AF-ALB, and liver function were analyzed. The Spearman correlation coefficients between these variables are presented in Table III. Significant correlations were found for high AF-ALB with low vitamin A $(-0.20)$, high total protein (0.19), high AST (0.17), and high ALT (0.31). High vitamin A was also significantly correlated with high vitamin E (0.47), low total protein $(-0.26)$, low albumin $(-0.17)$, low AST $(-0.21)$, and low ALT (-0.43). High vitamin E correlated significantly with low albumin $(-0.17)$ and low bilirubin $(-0.17)$. There was also a high positive correlation between vitamin $\mathrm{A}$ and $\mathrm{AFM}_{1}(0.31)$ and between $\mathrm{AFM}_{1}$ and albumin (0.36) (data not shown).

\section{Regression analysis}

Univariate regression models were used to conduct within-level comparisons of vitamin A, vitamin $\mathrm{E}$, and liver function according to AF-ALB and $\mathrm{AFM}_{1}$ levels (Table IV). The results indicated significant differences $(\mathrm{p}<0.05)$ between the levels of vitamin A, ALT and total protein in participants according to AF-ALB levels. Those with high AF-ALB had lower vitamin A concentrations, and higher ALT and total protein than those with low AF-ALB. A significant difference was also demonstrated between $\mathrm{AFM}_{1}$ and vitamin $\mathrm{A}$; however, individuals with high $\mathrm{AFM}_{1}$ levels also had high vitamin A concentrations ( $\left.\mathrm{p}=0.0007\right)$. 
There was also a significant difference between $\mathrm{AFM}_{1}$ and albumin levels ( $\left.\mathrm{p}=0.01\right)$; those with high $\mathrm{AFM}_{1}$ had higher levels of plasma albumin.

\section{Multivariate analyses}

We conducted multiple regression analyses to determine the direction and magnitude of AFALB and $\mathrm{AFM}_{1}$ on vitamin A and vitamin $\mathrm{E}$ levels in study participants. After adjusting for possible confounders such as age, sex, education, number of people in the household, hepatitis infection, total protein, albumin, bilirubin, and AST and ALT concentrations, multivariable analysis demonstrated that high AF-ALB was independently associated greater than a 2.6 fold increased risk of low vitamin A concentration (adjusted odds ratio, AOR = $2.61,95 \%$ confidence interval $(\mathrm{CI})=1.03-6.58, \mathrm{p}=0.04$; (Table V). Participants who were HBsAg- positive were almost 6 times as likely to have low vitamin A concentrations as those who were HBsAg- negative $(\mathrm{AOR}=5.88, \mathrm{CI}=1.71-20.14, \mathrm{p}=0.005)$. AF-ALB was marginally associated with vitamin $\mathrm{E}(\mathrm{AOR}=2.40,95 \% \mathrm{CI}=0.96-6.05, \mathrm{p}=0.06)$. Those with high AF-ALB were 2.4 times more likely to have low vitamin $\mathrm{E}$ than those with low AF-ALB, but this was not statistically significant.

Table VI demonstrates that higher levels of $\mathrm{AFM}_{1}$ was associated with reduced odds of having vitamin A deficiency, though this was not statistically significant $(\mathrm{OR}=0.31$, $95 \% \mathrm{CI}=0.09-1.02, \mathrm{p}=0.05)$. However, those with higher $\mathrm{AFM}_{1}$ levels had a significantly reduced odds of having vitamin $\mathrm{E}$ deficiency $(\mathrm{OR}=0.31,95 \% \mathrm{CI}=0.10-0.97, \mathrm{p}=0.04)$. Having a positive anti-HBsAg test result was significantly associated with vitamin A deficiency. Those who were anti-HBsAg positive were 5.84 times more likely to have low vitamin A than those who were anti-HBsAg negative $(\mathrm{AOR}=5.84, \mathrm{CI}=1.15-29.54, \mathrm{p}$ $=0.03)$.

\section{Discussion}

All of the participants in this study had AF-ALB albumin adducts in their plasma and 91.2\% excreted $\mathrm{AFM}_{1}$ in urine. These biological markers are objective indicators and more precise measures of aflatoxin exposure than measures of dietary exposure [47]. Whereas AF-ALB indicates aflatoxin exposure over a 2-3 month period, $\mathrm{AFM}_{1}$ indicates more recent exposure occurring in the last 24-48 hours [47]. Almost one third (32\%) of participants in the study were vitamin A-deficient and $73 \%$ were vitamin E-deficient. Our main hypothesis of interest was that aflatoxin exposure is associated with vitamin $\mathrm{A}$ and $\mathrm{E}$ concentrations. We found significant inverse relationships between AF-ALB levels and both vitamin A and $\mathrm{E}$ concentrations. Multivariate analysis showed a 2.64-fold greater risk of finding low vitamin A concentrations in participants with high AF-ALB levels. This is a very interesting finding, given the cross-sectional nature of the study and relatively small sample size. Decrease in vitamin A concentrations has been shown in animals exposed to aflatoxin in the diet [2932]. The only previous study that reported on AF-ALB and vitamin A levels in humans (children) found no association between these factors [48]. Our study indicates that vitamin A status is modulated by aflatoxin exposure. Preventing such exposure would be one way of greatly decreasing the occurrence of vitamin A deficiency in many developing countries, such as Ghana, where large portions of the populations face food insecurity and nutritional deficiency and are constantly exposed to aflatoxin in the diet. There was a marginal association between AF-ALB and vitamin E concentration ( $\mathrm{p}=0.06$ ). Those with high AFALB were 2.4 times more likely to be vitamin E-deficient than those with low AF-ALB. Harvey et al. [33] showed that dietary aflatoxin was associated with decreased levels of serum tocopherol and retinol concentrations in swine.

Contrary to the finding of an inverse relationship between AF-ALB and vitamin A concentration, there was a positive relationship between $\mathrm{AFM}_{1}$ and vitamin A. Multivariable 
analysis showed that those with high $\mathrm{AFM}_{1}$ had a $69 \%$ decreased chance of having low vitamin $\mathrm{A}$ than those with low $\mathrm{AFM}_{1} . \mathrm{AFM}_{1}$ is a metabolite of $\mathrm{AFB}_{1}$. Cytochrome $\mathrm{P} 450$ (CYP) enzymes mediate metabolism of $\mathrm{AFB}_{1}$ to $\mathrm{AFM}_{1}$. Koser et al. [49] reported that the CYP450 isoform that mediates $\mathrm{AFM}_{1}$ formation in the mouse is CYP 1-A2. It has also been shown CYP 1-A2 is the high-affinity $\mathrm{P} 450$ enzyme principally responsible for the bioactivation of $\mathrm{AFB}_{1}$ at low substrate concentrations associated with dietary exposure [50]. In the human body, vitamin A or retinol is oxidized via retinal to retinoic acid, which has pleiotrophic biological functions. The metabolism of retinals to retinoic acid is mediated by human CYP 1-A1, 1-A2, 1B 1 , and 3-A4 for the formation of all-trans-retinoic acid and CYP 1-A2 for the formation of 9-cis-retinoic acid. Zhang et al. [51] also showed that CYP 1-A2 is the isoform that most efficiently metabolizes 9-cis-retinal to 9-cis-retinoic acid. Our findings of a positive relationship between $\mathrm{AFM}_{1}$ and vitamin $\mathrm{A}$ may indicate that in the presence of $\mathrm{AFB}_{1}, \mathrm{CYP} 1-\mathrm{A} 2$ functions more actively in the breakdown of $\mathrm{AFB}_{1}$ to $\mathrm{AFM}_{1}$ than in the conversion of retinal to retinoic acid, thereby resulting in high levels of $\mathrm{AFM}_{1}$ simultaneously with high concentrations of retinol.

$\mathrm{AFM}_{1}$ was also positively associated with vitamin E concentration. Those with high $\mathrm{AFM}_{1}$ had a $69 \%$ less chance of having low vitamin E concentrations than those with low $\mathrm{AFM}_{1}$. $\mathrm{Yu}$ et al. [14] found that plasma concentrations of $\alpha$-tocopherol and $\alpha$ - and $\beta$-carotene were positively associated with $\mathrm{AFB}_{1}$-DNA adducts in urine of healthy males. These data were in accordance with findings of a previous in vitro study in which $\alpha$-tocopherol and $\beta$-carotene enhanced the $\mathrm{AFB}_{1}$-DNA adduct formation in cultured woodchuck hepatocytes [52]. Our finding suggests that vitamin $\mathrm{E}$ may enhance breakdown of $\mathrm{AFB}_{1}$ to $\mathrm{AFM}_{1}$ although the mechanism is not known.

Serum aminotransferases are the most useful measures of liver cell injury [53]. In our study, high AF-ALB was significantly associated with high ALT and high total protein and marginally associated with high AST. Aflatoxin induces injury to both hepatic parenchyma and the biliary tract [54]. Tao et al. [55] studied the relationships between aflatoxin albumin adducts and several liver-specific biochemical parameters. They found associations between AF-ALB and globulin and AST that suggest that AFB $_{1}$ modified the immune response and induced damage to hepatic parenchymal cells [55]. These associations have previously been reported in other $[54,56,57]$ but not all [58-60] animal studies. The mechanism of $\mathrm{AFB}_{1^{-}}$ induced cellular damage is not fully understood. However, it has been shown that $\mathrm{AFB}_{1}$ can stimulate the release of free radicals including reactive oxygen species, which lead to chromosomal damages [61]. This has been supported by other studies [62-64]. Rastogi et al. [62] observed significant elevations in the levels of serum transaminases, other liver enzymes, and bilirubin following $\mathrm{AFB}_{1}$ administration to rats.

We found an association between high AF-ALB and high total protein. Very few studies were found in a search of the literature on the effect of aflatoxin on serum proteins and the results have been contradictory $[65,66]$. Thurston et al. [65] reported that guinea pigs given aflatoxin in the diet had an increase in albumin and gamma-globulin and a decrease in $\alpha 1-$, $\alpha 2$-and $\beta$-globulin compared to the controls, while Richard et al. [66] found that aflatoxin significantly decreased total serum protein and found no significant increase in gammaglobulin in guinea pigs. The differences may be due to the dosage and regimens used in the different experiments. Aflatoxin has been shown to suppress antibody formation to the typhoid vaccine in mice [67] and in chickens injected with sheep erythrocytes [68]. Swine and turkeys fed aflatoxin also had increased gamma-globulin levels [69, 70].

Having a positive HBsAg test result was also a strong independent predictor of low vitamin A concentration. Those who were HBsAg- positive were almost 6 times as likely to have low vitamin A concentration as those who were HBsAg-negative. Hepatitis B virus causes 
inflammation of the liver and ongoing liver damage. Vitamin A metabolism and storage occur in the liver. Liver hepatocytes govern the uptake, transfer, metabolism, and homeostasis of vitamin A. It was previously reported $[53,71]$ that serum concentrations of vitamin A were lower in individuals with chronic liver diseases and were related to the severity of the condition. Hepatic stellate cells that mediate liver fibrosis are usually affected as a result of liver injury and could lead to vitamin A deficiency [72]. It is also possible that defective synthesis of the serum aminotransferases as a result of liver injury could prevent mobilization or impair absorption of vitamin A from the hepatic stellate cells [73].

Our study has some potential limitations, the most apparent of which is that it Is crosssectional in design and sp, the temporal relationships between AF-ALB biomarker levels and vitamin $\mathrm{A} / \mathrm{E}$ deficiencies could not be established. To determine whether the association between $\mathrm{AFB}_{1}$ and micronutrient status is a direct result of aflatoxin exposure requires a longitudinal study. Secondly, our small sample size limited our ability to detect small associations and yielded imprecise estimates. Furthermore, the effects of dietary exposure to aflatoxin might be complicated by confounding factors such as socioeconomic status or malnutrition. However, the potential bias introduced by these factors was minimized by including some of these variables in the regression models.

In conclusion, our findings demonstrated that there is a significant negative relationship between exposure to $\mathrm{AFB}_{1}$ and plasma concentrations of vitamins $\mathrm{A}$ and $\mathrm{E}$ in our study population. Vitamin A is stored in the liver and evidence from the serum markers for liver function showed that exposure to aflatoxin (and possibly HBV infection) had a negative impact on the liver and may contribute to vitamin A deficiency. Vitamin A deficiency has been shown to contribute to impaired cellular differentiation, depressed immune response, and increased chronic and infectious disease morbidity and mortality. Vitamin $\mathrm{E}$ has been shown to improve cellular immunity and decrease the occurrence of some cancers. Efforts in advancing global understanding and preventing vitamin $\mathrm{A}$ and $\mathrm{E}$ deficiencies should strongly consider the impact of aflatoxin exposure.

\section{Acknowledgments}

We are grateful to the District Health Director, Physician, Pharmacist, Environmental Field Officers, and other health personnel at the Ejura District Hospital for their assistance. We especially thank the participants who made this study possible. We thank the Directors and other laboratory personnel at the Kumasi Center for Collaborative Research (KCCR) in Tropical Diseases, KNUST for assistance with cell separation, storage and shipping. We thank Jia-Sheng Wang for assistance with AFB 1 analysis.

Sources of financial support: USAID grant LAG-G-00-96-90013-00 for the Peanut Collaborative Support Research Program, University of Georgia, Athens, GA, USA, NIH Cancer Prevention and Control Training Program Grant CA 47888 and Minority Health International Research Training (MHIRT) grant \# T37-MD001448 from the National Center on Minority Health and Health Disparities, National Institutes of Health, Bethesda, MD, USA

\section{Literature Cited}

1. Underwood BA. Vitamin A deficiency disorders: international efforts to control a preventable "pox". J Nutr. 2004; 134:S231.

2. West KP Jr. Extent of vitamin A deficiency among preschool children and women of reproductive age. J Nutr. 2002; 132:S2857.

3. West KP Jr, Katz J, Khatry SK, et al. Double blind, cluster randomised trial of low dose supplementation with vitamin A or $\beta$-carotene on mortality related to pregnancy in Nepal. The NNIPS-2 Study Group. Br Med J. 1999; 318:570. [PubMed: 10037634]

4. Christian P, West KP Jr, Khatry SK, et al. Vitamin A or $\beta$-carotene supplementation reduces symptoms of illness in pregnant and lactating Nepali women. J Nutr. 2001; 130:2675. [PubMed: 11053506] 
5. Semba R, Vitamin A. Immunity, and Infection. Clin Infect Dis. 1994; 19:489. [PubMed: 7811869]

6. Markowitz L, Nzilambi N, Driskell WJ, et al. Vitamin A levels and mortality among hospitalized measles patients, Kinshasa. Zaire. J Trop Pediatr. 1989; 35:109. [PubMed: 2754767]

7. Sommer A, Katz J, Tarwotjo I. Increased risk of respiratory disease and diarrhea in children with preexisting mild vitamin A deficiency. Am J Clin Nutr. 1984; 40:1090. [PubMed: 6496388]

8. Semba RD. Vitamin A and immunity to viral, bacterial, and protozoan infections. Proc Nutr Soc. 1999; 58:719. [PubMed: 10604208]

9. Jiang Y, Obuseh F, Ellis W, Piyanthilake C, Jolly P. Association of vitamin A deficiency with decrease in tumor necrosis factor $\alpha$ expressing CD3-CD56+ natural killer cells in Ghanaians. Nutr Res. 2007; 27:400. [PubMed: 18591985]

10. Yu MW, Hsieh HH, Pan WH, Yang CS, Chen CJ. Vegetable consumption, serum retinol level and risk of hepatocellular carcinoma. Cancer Res. 1995; 55:1301. [PubMed: 7882326]

11. Huang CC, Hsueh JL, Chen HH, Batt TR. Retinol (vitamin A) inhibits sister chromatid exchanges and cell cycle delay induced by cyclophosphamide and aflatoxin $\mathrm{B}_{1}$ in Chinese hamster V79 cells. Carcinogenesis. 1982; 3:1. [PubMed: 6802508]

12. Kantoch M, Litwinska B, Szkoda M, Siennicka J. Importance of vitamin A deficiency in pathology and immunology of viral infections. Rocz Panstw Zakl Hig. 2002; 53:385. [PubMed: 12664666]

13. Lee CY, Man-Fan WJ. Vitamin E supplementation improves cell-mediated immunity and oxidative stress of Asian men and women. J Nutr. 2000; 130:2932. [PubMed: 11110849]

14. Yu MW, Chiang YC, Lien JP, Chen CJ. Plasma antioxidant vitamins, chronic hepatitis B virus infection and urinary aflatoxin B1-DNA adducts in healthy males. Carcinogenesis. 1997; 18:1189. [PubMed: 9214602]

15. Tang AM, Graham NM, Semba RD, Saah AJ. Association between serum vitamin A and E levels and HIV-1 disease progression. AIDS. 1997; 11:613. [PubMed: 9108943]

16. Gourama H, Bullerman LB. Aspergillus flavus and Aspergillus parasiticus, aflatoxigenic fungi of concern in foods and feed-a review. J Food Protect. 1995; 8:1395.

17. Center for Disease Control and Prevention (CDC). Outbreak of aflatoxin poisoning - Easter and Central Provinces, Kenya; MMWR. 2004 January-June. p. 790

18. Lewis L, Onsongo M, Njapau H, et al. Aflatoxin Contamination of Commercial Maize Products during an Outbreak of Acute Aflatoxicosis in Eastern and Central Kenya. Environ Hleath Perspect. 2005; 113:1763.

19. Wilson, DM.; Payne, GA.; Groopman, J. Factors Affecting Aspergillus flavus Group Infection and Aflatoxin Contamination of Crops. In: Eaton, DL.; Groopman, JD., editors. The Toxicology of Aflatoxin: Human Health, Veterinary, and Agricultural Significance. San Diego: Academic Press; 1994. p. 309

20. Begum F, Samajpati N. Mycotoxin production production on rice, pulses and oilseeds. Naturwissenschaften. 2000; 87:275. [PubMed: 10929292]

21. Kpodo K, Thrane U, Hald B. Fusaria and fumonisins in maize from Ghana and their co-occurrence with aflatoxins. Int. J Food Microbiol. 2000; 61:147. [PubMed: 11078165]

22. Awuah RT, Kpodo KA. High incidence of Aspergillus flavus and aflatoxins in stored groundnut in Ghana and the use of a microbial assay to assess the inhibitory effects of plant extracts on aflatoxin synthesis. Mycopathologia. 1996; 134:109. [PubMed: 8981776]

23. Wands JR, Blum HE. Primary hepatocellular carcinoma. N Engl J Med. 1991; 325:729. [PubMed: 1651454]

24. Sodeinde O, Chan MC, Maxwell SM, Familusi JB, Hendrickse RG. Neonatal jaundice, aflatoxins and naphthols: report of a study in Ibadan, Nigeria. Ann Trop Paediatr. 1995; 15:107. [PubMed: 7677410]

25. Ahmed H, Hendrickse RG, Maxwell SM, Yakubu AM. Neonatal jaundice with reference to aflatoxins: an aetiological study in Zaria, northern Nigeria. Ann Trop Paediatr. 1995; 15:11. [PubMed: 7598431]

26. Abdulrazzaq YM, Osman N, Yousif AM, Trad O. Morbidity in neonates of mothers who have ingested aflatoxins. Ann Trop Paediat. 2004; 24:145. 
27. Egbunike GN, Emerole GO, Aire TA, Ikegwuonu FI. Sperm production rates, sperm physiology and fertility in rats chronically treated with sublethal doses of aflatoxin B1. Andrologia. 1980; 12:467. [PubMed: 6778257]

28. Miller, DM.; Wilson, DM. Veterinary Diseases Related to Aflatoxins. In: Eaton, DL.; Groopman, JD., editors. The Toxicology of Aflatoxin: Human Health, Veterinary, and Agricultural Significance. San Diego: Academic Press; 1994. p. 347

29. Abdelhamid AM, el-Shawaf I, el-Ayoty SA, Ali MM, Gamil T. Effect of low level of dietary aflatoxins on baladi rabbits. Arch Tierernahr. 1990; 40:517. [PubMed: 2241571]

30. Pimpukee K, Kubena LF, Bailey CA, Huebner HJ, Afriyie-Gyawu E, Phillips TD. Aflatoxininduced toxicity and depletion of hepatic vitamin A in young broiler chicks in the presence of low levels of Novasil Plus TM in the diet. Poult Sci. 2004; 83:737. [PubMed: 15141830]

31. Reddy KV, Rao PV, Reddy VR. Effect of alfatoxin on the performance of broiler chicks fed diets supplemented with viramin A. Indian J Anim Sci. 1989; 59:140.

32. Abbas T, Ali B. Retinol values in the plasma of the Arabian camel (Camelus dromedarius) and the influence of aflatoxicosis. Vet Res Commun. 2001; 25:517. [PubMed: 11519683]

33. Harvey RB, Kubena LF, Elissalde MH. Influence of vitamin E on aflatoxicosis in growing swine. Am J Vet Res. 1994; 55:572. [PubMed: 8017706]

34. Nyandieka HS, Wakhisi J. The impact of vitamins A, C, E, and selenium compound on prevention of liver cancer in rats. East Afr Med J. 1993; 70:151. [PubMed: 8261941]

35. Gradelet S, Astorg P, Le Bon AM, Berges R, Suschetet M. Modulation of aflatoxin B1 carcinogenicity, genotoxicity and metabolism in rat liver by dietary carotenoids: evidence for a protective effect of CYP1A inducers. Cancer Lett. 1997; 114:221. [PubMed: 9103297]

36. Verma RJ, Nair A. Vitamin E ameliorates aflatoxin-induced biochemical changes in the testis of mice. Asian J Androl. 2001; 3:305. [PubMed: 11753477]

37. Nyandieka HS, Wakhis J, Kilonzo MM. Association of reduction of AFB1-induced liver tumours by antioxidants with increased activity of microsomal enzymes. Indian J Med Res. 1990; 92:332. [PubMed: 2125579]

38. Stacewicz-Sapuntzakis M, Bowen PE, Kikendall JW, Burgess M. Simultaneous determination of serum retinol and various carotinoids: their distribution in middle-age men and women. $\mathrm{J}$ Micronutr Anal. 1987; 3:27.

39. Wang JS, Qian GS, Zarba A, et al. Temporal patterns of aflatoxin-albumin adducts in hepatitis B surface antigen-positive and antigen-negative residents of Daxin, Qidong County, People's Republic of China. Cancer Epidemiol Biomarkers Prevention. 1996; 5:253.

40. Gange SJ, Munoz A, Wang JS, Groopman JD. Variability of molecular biomarker measurements from nonlinear calibration curves. Cancer Epidemiol Biomarkers Prev. 1996; 5:57. [PubMed: 8770468]

41. Groopman JD, Zhu J, Donoahue PR, Pikul A, Zhang L, Chen JS, Wogan GN. Molecular dosimetry of urinary aflatoxin-DNA adducts in people living in Guangxi Autonomous Region, People's Republic of China. Cancer Res. 1992; 52:45. [PubMed: 1727385]

42. Groopman JD, Hasler JA, Trudel LJ, Pikul A, Donahue PR, Wogan GN. Molecular dosimetry in rat urine of aflatoxin-N7-guanine and other aflatoxin metabolites by multiple monocloncal antibody affinity chromatography and immunoaffinity/high performance liquid chromatography. Cancer Res. 1992; 52:267. [PubMed: 1728400]

43. Sarr AB, Mayura K, Kubena LF, Harvey RB, Phillips TD. Effects of phyllosilicate clay on the metabolic profile of aflatoxin B1 in Fisher-344 rats. Toxicol Lett. 1995; 75:145. [PubMed: 7863521]

44. Wang JS, Shen X, He X, et al. Protective alterations in phase 1 and 2 metabolism of aflatoxin B1 by oltipraz in residents of Qidong, People's Republic of China. J Natl Cancer Instit. 1999; 91:347.

45. Jolly P, Jiang Y, Ellis W, Awuah R, et al. Determinants of aflatoxin levels in Ghanaians: Sociodemographic factors, knowledge of aflatoxin and food handling and consumption practices. Int. J. Hyg. Environ Health. 2006; 209:345. [PubMed: 16644281]

46. World Health Organization. Micronutrient Deficiency Information System. Geneva: World Health Organization; 1995. WHO Global prevalence of vitamin A deficiency. MDIS Working paper \#2 WHO/NUT/95.3 
47. Hall, AJ.; Wild, CP. Epidemiology of Aflatoxin-Related Disease. In: Eaton, DL.; Groopman, JD., editors. The Toxicology of Aflatoxin: Human Health, Veterinary, and Agricultural Significance. San Diego: Academic Press; 1994. p. 233

48. Turner PC, Moore SE, Hall AJ, Prentice AM, Wild CP. Modification of immune function through exposure to dietary aflatoxin in Gambian children. Envrion Health Perspect. 2003; 111:217.

49. Koser PL, Faletto MB, Maccubbia AE, Gurtoo HL. The genetics of aflatoxin $\mathrm{B}_{1}$ metabolism. Association of the induction of aflatoxin $\mathrm{B}_{1}$-4-hydroxylase with the transcriptional activation of cytochrome $\mathrm{P}_{3}-450$ gene. J Biol Chem. 1988; 263:12584. [PubMed: 3137229]

50. Gallagher EP, Wienkers LC, Stapleton PL, Kunze K, Eaton DL. Role of human microsomal and human complementary DNA-expressed cytochromes P4501A2 and P4503A4 in the bioactivation of aflatoxin B1. Cancer Res. 1994; 54:101. [PubMed: 8261428]

51. Zhang QY, Dunbar D, Kaminsky L. Human Cytochrome P-450 Metabolism of Retinals to Retinoic Acids. Drug Metabolism Disposition. 2000; 28:292.

52. Yu MW, Chiang YJ, Blaner WS, Santella RM. Influence of vitamins A, C and E and beta carotene on aflatoxin B binding to DNA in woodchuck hepatocytes. Cancer. 1994; 73:596. [PubMed: 8299081]

53. Higashi N, Sato M, Kojima N, Irie T, Kawamura K, Mabuchi A, Senoo H. Vitamin A storage in hepatic stellate cells in the regenerating rat liver: with special reference to zonal heterogeneity. Anat Rec A Discov Mol Cell Evol Biol. 2005; 286:899. [PubMed: 16086432]

54. Barton CC, Hill DA, Yee SB, Barton EX, Ganey PE, Roth RA. Bacterial lipipolysaccharide exposure augments aflatoxin B(1)-induced liver injury. Toxicol Sci. 2000; 55:444. [PubMed: 10828277]

55. Tao P, Zhi-Ming L, Tang-Wei L, et al. Associated factors in modulating aflatoxin B1-albumin adduct level in three Chinese ppulations. Digest Dis Sci. 2005; 50:525. [PubMed: 15810636]

56. Moundipa PF, Domngang FM. Effect of the leafy vegetable Solanum nigrum on the activities of some liver drug-metabolizing enzymes after aflatoxin B1 treatment in female rats. Br J -Nutr. 1991; 65:81. [PubMed: 1900029]

57. Yousef MI, Salem MH, Kamel KI, Hassan GA, El Nouty FD. Influence of ascorbic acid supplementation on the haematolgical and clinical biochemistry paramters of male rabbits exposed to afaltoxin B1. J Environ Sci Health B. 2003; 38:193. [PubMed: 12617557]

58. Singh J, Tiwari RP, Singh G, Singh S, Vadehra DV. Biochemical and immunological effects of aflatoxins in rabbits. Toxicol Lett. 1987; 35:225. [PubMed: 3824411]

59. Clark JD, Hatch RC, Miller DM, Jain AV. Caprine aflatoxicosis: experimental disease and clinical pathologic changes. Am J Vet Res. 1984; 45:1132. [PubMed: 6430134]

60. Cheng YH, Shen TF, Pang VF, Chen BJ. Effects of aflatoxin and carotenoids on growth performance and immune response in mule ducklings. Comp Biochem Physiol C Toxicol Pharmacol. 2001; 128:19. [PubMed: 11166670]

61. Amstad P, Levy A, Emerit I, Cerutti P. Evidence for membrane mediated chromosomal damage by aflatoxin B1 in human lymphocytes. Carcinogenesis. 1984; 5:719. [PubMed: 6426812]

62. Rastogi R, Srivastava AK, Rastogi AK. Biochemical changes induced in liver and serum of aflatoxin-B1-treated male Wistar rats : Preventive effect of Picroliv. Pharmacol Toxicol. 2001; 88:53. [PubMed: 11169162]

63. Nakae D, Konishi Y, Farber JL. A role for oxygen radicals in the hepatotoxicity of aflatoxin B1 and dimethyl nitrosamine. Proc Jap Cancer Assoc. 1987:38.

64. Shen HM, Shi CY, Lee HP, Ong CN. Aflatoxin B1 induced lipid peroxidation in rat liver. Toxicol Appl Pharmacol. 1994; 127:145. [PubMed: 8048046]

65. Thurston JR, Deyoe BL, Baetz AL, Richard JL, Booth GD. Effect of aflatoxin on serum proteins, complement activity and the antibody response to Brucella abortus in guinea pigs. Amer J Vet Res. 1974; 35:1132.

66. Richard JL, Thurston JR, Deyoe BL, Booth GD. Effect of ochratoxin and aflatoxin on serum proteins complement activity and antibody production to Brucella abortus in guinea pigs. Applied Microbiol. 1975; 29:27.

67. Galikeev KH, Raipov OR, Manyasheva RA. Effect of aflatoxin on dynamics of antibody formation. Byul Eklsp Biol Med. 1968; 65:88. 
68. Tung HT, Wyatt RD, Thaxton P, Hamilton PB. Concentrations of serum proteins during aflatoxicosis. Toxicol Appl Pharmacol. 1975; 34:320. [PubMed: 1209630]

69. Annau E, Conner AH, Magwood SE, Jericho K. Electrophoretic and chemical studies on sera of swine following the feeding of toxic groundnut meal. Can J Comp Med Vet Sci. 1964; 28:264. [PubMed: 17649538]

70. Richard JL, Pier AC, Cysewski SJ, Graham CK. Effect of aflatoxin and aspergillosis in turkey poults. Avian Dis. 1973; 17:111. [PubMed: 4633271]

71. Newsome PN, Beldon I, Moussa Y, et al. Low serum retinol levels are associated with hepatocellular carcinoma in patients with chronic liver disease. Aliment Pharmacol Ther. 2000; 14:1295. [PubMed: 11012474]

72. Bataller R, Brenner DA. Liver fibrosis. J Clin Invest. 2005; 115:209. [PubMed: 15690074]

73. Fortuna VA, Martucci RB, Trugo LC, Borojevic R. Hepatic stellate cells uptake of retinol associated with retinol-binding protein or with bovine serum albumin. J Cell Biochem. 2003; 90:792. [PubMed: 14587034] 
Table I

Sociodemographic and biological characteristics of the study population by sex

\begin{tabular}{|c|c|c|c|c|}
\hline & $\begin{array}{l}\text { Total N=147 } \\
\text { n (\%) }\end{array}$ & $\begin{array}{c}\text { Male } N=79 \\
\text { n }(\%)\end{array}$ & $\begin{array}{c}\text { Female } N=68 \\
\text { n }(\%)\end{array}$ & P-value \\
\hline Age (years) & & & & 0.44 \\
\hline $19-39$ & 88 (59.9) & $45(57.0)$ & $43(63.2)$ & \\
\hline$>40$ & $59(40.1)$ & $34(43.0)$ & $25(36.8)$ & \\
\hline Ethnicity & & & & 0.40 \\
\hline Akans & $54(37.8)$ & $26(33.8)$ & $28(42.4)$ & \\
\hline Dagbani & $26(18.2)$ & $13(16.9)$ & $13(19.7)$ & \\
\hline Ewes & $1(0.7)$ & $1(1.3)$ & $0(0.0)$ & \\
\hline Gruma & $9(6.3)$ & $8(10.4)$ & $1(1.5)$ & \\
\hline Grussi & $2(1.4)$ & $1(1.3)$ & $1(1.5)$ & \\
\hline Hausa & $2(1.4)$ & $1(1.3)$ & $1(1.5)$ & \\
\hline Other & $49(34.3)$ & $27(35.1)$ & $22(33.3)$ & \\
\hline Formal Education & & & & 0.0004 \\
\hline No & $75(51.7)$ & $27(34.6)$ & $43(64.2)$ & \\
\hline Yes & $70(48.3)$ & $51(65.4)$ & $24(35.8)$ & \\
\hline Intake of Alcohol & & & & 0.05 \\
\hline No & $102(76.1)$ & $53(69.7)$ & $49(84.5)$ & \\
\hline Yes & $32(23.9)$ & $23(30.3)$ & $9(15.5)$ & \\
\hline Occupation & & & & $<.0001$ \\
\hline Farmer & $71(50.3)$ & $44(58.7)$ & $27(40.9)$ & \\
\hline Trader & $25(17.7)$ & $5(6.7)$ & $20(30.3)$ & \\
\hline Farmer/Trader & $7(5.0)$ & $0(0.0)$ & $7(10.6)$ & \\
\hline Farmer/other & $7(5.0)$ & $6(8.0)$ & $1(1.5)$ & \\
\hline Other & $31(22.0)$ & $20(26.7)$ & $11(16.7)$ & \\
\hline Hepatitis B Infection & & & & 0.26 \\
\hline No & $123(84.3)$ & $69(87.3)$ & $54(80.6)$ & \\
\hline Yes & $23(15.7)$ & $10(12.7)$ & $13(19.4)$ & \\
\hline Hepatitis C Infection & & & & 0.14 \\
\hline No & $123(84.8)$ & $63(80.8)$ & $60(89.5)$ & \\
\hline Yes & $22(15.2)$ & $15(19.2)$ & $7(10.5)$ & \\
\hline Vitamin $A(\mu \mathrm{mol} / \mathrm{L})$ & & & & 0.60 \\
\hline Low $(<0.698 \mu \mathrm{mol} / \mathrm{L})$ & $46(31.7)$ & $23(29.9)$ & $23(33.8)$ & \\
\hline $\operatorname{High}(\geq 0.698 \mu \mathrm{mol} / \mathrm{L})$ & $99(68.3)$ & $54(70.1)$ & $45(66.2)$ & \\
\hline Vitamin $E(\mu \mathrm{mol} / \mathrm{L})$ & & & & 0.63 \\
\hline Low $(<11.61 \mu \mathrm{mol} / \mathrm{L})$ & $106(73.1)$ & $55(71.4)$ & $51(75.0)$ & \\
\hline
\end{tabular}




\begin{tabular}{|l|c|c|c|c|}
\hline & $\begin{array}{c}\text { Total N=147 } \\
\text { n (\%) }\end{array}$ & $\begin{array}{c}\text { Male N=79 } \\
\text { n (\%) }\end{array}$ & $\begin{array}{c}\text { Female N=68 } \\
\text { n(\%) }\end{array}$ & P-value \\
\hline High $(\geq 11.6 \mu \mathrm{mol} / \mathrm{L})$ & $39(26.9)$ & $22(28.6)$ & $17(25.0)$ & \\
\hline AF_ALB (pmol/mg AL) & & & & 0.23 \\
Low (<0.8 pmol/mg AL) & $71(48.6)$ & $42(53.2)$ & $29(43.3)$ & \\
High ( $\geq 0.8 \mathrm{pmol} / \mathrm{mg}$ AL) & $75(51.4)$ & $37(46.8)$ & $38(56.7)$ & \\
\hline Aflatoxin M1 (pg/dL creatinine) & & & & \multirow{2}{*}{0.12} \\
Low (<437.95 pg/dL) & $41(50.0)$ & $19(42.2)$ & $22(59.5)$ & \\
High $(\geq 437.95 \mathrm{pg} / \mathrm{dL})$ & $41(50.0)$ & $26(57.8)$ & $15(40.5)$ & \\
\hline
\end{tabular}

$\mathrm{AF}-\mathrm{ALB}=$ aflatoxin $\mathrm{B} 1$ albumin adducts 
Table II

Descriptive sociodemographic and biological characteristics of the study population by vitamin A status

\begin{tabular}{|c|c|c|c|}
\hline Variables & $\begin{array}{c}\text { High Vit. A }(\mathrm{N}=69) \\
n(\%)\end{array}$ & $\begin{array}{c}\text { Low Vit. A }(\mathrm{N}=46) \\
n(\%)\end{array}$ & P-value \\
\hline Age & & & 0.56 \\
\hline $19-39$ & $61(61.6)$ & $26(56.5)$ & \\
\hline$>40$ & $38(38.4)$ & $20(43.5)$ & \\
\hline Gender & & & 0.61 \\
\hline Male & $54(54.6)$ & $23(50.0)$ & \\
\hline Female & $45(45.4)$ & $23(50.0)$ & \\
\hline Ethnicity & & & 0.05 \\
\hline Akans & $29(30.5)$ & $23(50.0)$ & \\
\hline Dagbani & $17(17.9)$ & $9(19.6)$ & \\
\hline Ewes & $1(1.1)$ & $0(0.0)$ & \\
\hline Gruma & $4(4.2)$ & $5(10.9)$ & \\
\hline Grussi & $2(2.1)$ & $0(0.0)$ & \\
\hline Hausa & $2(2.1)$ & $0(0.0)$ & \\
\hline Other & $40(42.1)$ & $9(19.6)$ & \\
\hline Formal Education & & & 0.21 \\
\hline No & $51(52.6)$ & $19(41.3)$ & \\
\hline Yes & $46(47.4)$ & $27(58.7)$ & \\
\hline Intake of Alcohol & & & 0.81 \\
\hline No & $66(75.9)$ & $35(77.8)$ & \\
\hline Yes & $21(24.1)$ & $10(22.2)$ & \\
\hline Occupation & & & 0.29 \\
\hline Farmer & $53(54.6)$ & $17(40.5)$ & \\
\hline Trader & $13(13.4)$ & $12(28.6)$ & \\
\hline Farmer/Trader & $5(5.2)$ & $2(4.8)$ & \\
\hline Farmer/other & $5(5.2)$ & $2(4.8)$ & \\
\hline Other & $21(21.6)$ & $9(21.4)$ & \\
\hline Hepatitis B Infection & & & 0.02 \\
\hline No & $87(88.8)$ & $34(73.9)$ & \\
\hline Yes & $11(11.2)$ & $12(26.1)$ & \\
\hline Hepatitis C Infection & & & 0.70 \\
\hline No & $82(84.5)$ & $40(87.0)$ & \\
\hline Yes & $15(15.5)$ & $6(13.0)$ & \\
\hline Vitamin $E(\mu \mathrm{mol} / \mathrm{L})$ & & & 0.001 \\
\hline $\operatorname{High}(\geq 11.61 \mu \mathrm{mol} / \mathrm{L})$ & $27(27.3)$ & $2(4.4)$ & \\
\hline
\end{tabular}




\begin{tabular}{|l|c|c|c|}
\hline Variables & $\begin{array}{c}\text { High Vit. A (N=69) } \\
\mathbf{n}(\%)\end{array}$ & $\begin{array}{c}\text { Low Vit. A (N= 46) } \\
\text { n(\%) }\end{array}$ & P-value \\
\hline Low $(<11.61 \mu \mathrm{mol} / \mathrm{L})$ & $72(72.7)$ & $44(95.6)$ & \\
\hline AF-ALB (pmol/mg AL) & & & 0.005 \\
Low (<0.8 pmol/mg AL) & $56(56.6)$ & $14(31.1)$ & \\
High ( $\geq 0.8 \mathrm{pmol} / \mathrm{mg}$ AL) & $43(43.4)$ & $31(68.9)$ & \\
\hline Aflatoxin M1 (pg/dL creatinine) & & & 0.02 \\
Low (<437.95 pg/dL) & $23(41.1)$ & $18(69.2)$ & \\
High $(\geq 437.95 \mathrm{pg} / \mathrm{dL})$ & $33(58.9)$ & $8(30.8)$ & \\
\hline
\end{tabular}

Vit. A = Vitamin A; Vitamin A concentration: High $=\geq 20 \mu \mathrm{g} / \mathrm{dL} ;$ low $=\langle 20 \mu \mathrm{g} / \mathrm{dL}) ;$ AF-ALB=aflatoxin B1 albumin adducts 


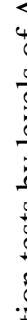




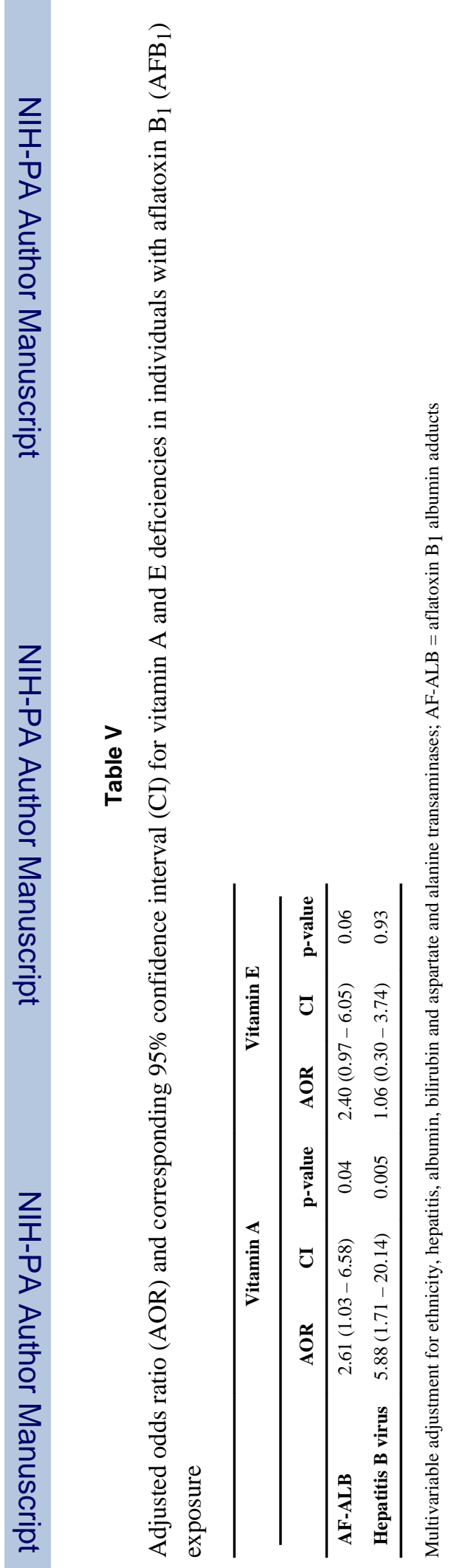




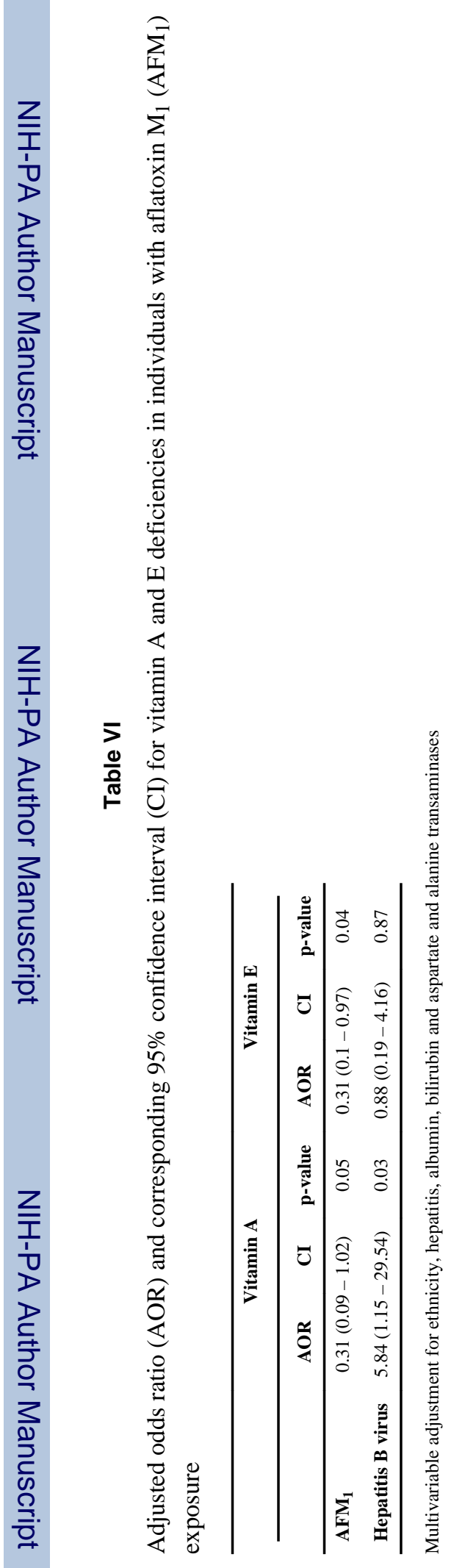

